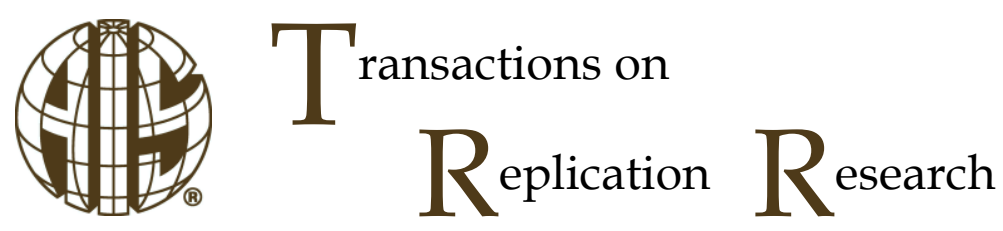

\title{
What Drives Online Repurchase Intention? A Replication of the Moderating Role of Perceived Effectiveness of E-Commerce Institutional Mechanisms
}

\author{
Phil Diegmann \\ University of Cologne, Cologne, Germany \\ diegmann@wiso.uni-koeln.de \\ Can Dogan \\ University of Cologne, Cologne, Germany \\ can-dogan@gmx.net \\ Dirk Basten \\ University of Cologne, Cologne, Germany \\ basten@wiso.uni-koeln.de \\ Martin Brandt \\ University of Cologne, Cologne, Germany \\ martin.brandt93@web.de \\ Christoph Rosenkranz \\ University of Cologne, Cologne, Germany \\ rosenkranz@wiso.uni-koeln.de
}

\section{Abstract:}

\begin{abstract}
Online retailing is growing rapidly and customer retention has become increasingly important, especially trust and ecommerce institutional mechanisms such as online credit card guarantees, escrow services, and privacy protection, which have become more significant and the subject of recent research (Fang et al., 2014). We conducted a methodological replication of first insights and a model of the relation between satisfaction, trust, repurchase intention and the perceived effectiveness of such e-commerce institutional mechanisms (PEEIM). As we were unable to support the original findings, we provide an alternative reasoning relevant to today's role of PEEIM for online repurchases and discuss implications for research and practice.
\end{abstract}

Keywords: Online Shopping, Repurchase Intention, E-Commerce, Institutional Mechanisms, Vendor Satisfaction, Trust, Partial Least Squares Structural Equation Modeling, Moderation Analysis, Panel, Replication

The manuscript was received 10/16/2016 and was with the authors eight months for three revisions.

\section{Introduction}

Online retailing has grown rapidly within the past decade. As online retailers face the challenge of retaining customers, identifying factors influencing customer decisions for repeated purchases (i.e., repurchases) has become increasingly important in recent years (Johnson, Hult, \& McGowan, 2008). Trust has been found to be a key predictor of customer retention in online retailing (e.g., Flavián, Guinalíu, \& Gurrea, 2006; Gefen, 2002; Qureshi et al., 2009), and researchers have called for an examination of the moderating effect of the e-commerce institutional context (i.e., the safeguarding, regulatory structures for the transaction environment, Zucker, 1986) on the relationship between trust and online repurchase (Gefen, Benbasat, \& Pavlou, 2008).

Fang et al. (2014) set out to investigate this effect empirically to help specifying how and under which conditions trust influences online repurchase, and to provide a rationale for previously unexpected results in the literature regarding customer loyalty in e-commerce settings. The authors extended the moderating role of customer loyalty by accounting for customer satisfaction because past experience in a purchase situation can serve as an important factor for evaluating trust (McKnight, Cummings, \& Chervany, 1998). The first test of their model provided confirmatory results. 
To provide additional empirical evidence and to extend the theory to a new context, we replicated the study by Fang et al. (2014). Our replication answers the general call for more replication in the field of information systems (e.g., Dennis \& Valacich, 2014; Morrison, Matuszek, \& Self, 2010; Niederman \& March, 2015). We decided to replicate the study of Fang et al. (2014) because of the importance of their findings for ecommerce related research and practice. Furthermore, replication research has become a field of interest among scholars due to a high number of non-replicable findings (Lindsay, 2015; Morrison et al., 2010; Niederman \& March, 2015), which "are of no significance to science" (Popper, 2005, p. 66). To the best of our knowledge, as no other replications of this study exist, we suggest that a replication of the study by Fang et al. (2014) could provide helpful benefits to both research and practice. Thus, our replication aims at providing either further evidence for the original study's findings or additional boundaries for the scope of applicability.

The remainder of this paper is structured as follows. First, we describe the original study as well as our replication approach. Second, we describe the research model and related hypotheses. Third, we describe the research methodology applied and the results gained from data analysis. We then discuss our paper's findings, limitations, and avenues for future research. Our study ends with a short conclusion.

\subsection{Overview of Original Research}

The original study by Fang et al. (2014) explored the moderating effect of the e-commerce institutional context. It investigated the perceived effectiveness of e-commerce institutional mechanisms (PEEIM) as a manifestation of the institutional context. According to the authors, PEEIM refers to "online customer perceptions that third-party safeguarding mechanisms, such as online credit card guarantees, escrow services and privacy protection exist to protect them against potential risks in the e-commerce environment" (Fang et al., 2014, p. 409) and is distinguished from other, similar concepts by measuring perceptions regarding the institutional environment independent of the vendor and its ability to mitigate risks (Fang et al., 2014).

Fang et al. (2014) propose a model that tests an effect of satisfaction with vendor (SV) on repurchase intention (RPI), mediated by trust in vendor (TV). Furthermore, they suggest a direct effect of SV on RPI. Aside from this basic model, the authors propose the moderating effects of PEEIM on the effects of SV on TV $\left(\mathrm{H}_{2}\right)$ and on the relation of TV with RPI $\left(\mathrm{H}_{1}\right)$. They suggest a positive moderation for $\mathrm{H}_{2}$ and a negative one for $\mathrm{H}_{1}$. Additionally, they account for different control variables with an influence on both TV and RPI.

The authors tested their research model by using partial least squares (PLS) as a structural equation modeling approach with data from a sample generated among students and faculty members (Fang et al., 2014). Their sample consisted of 362 usable responses (see Appendix A for more information). The most commonly bought items were air tickets $(n=92)$, followed by books $(n=42)$. Figure 1 shows the research model results obtained in the study by Fang et al. (2014). The authors were able to support both $\mathrm{H}_{1}$ and $\mathrm{H}_{2}$ and only three control variables had significant effects: vendor reputation and perceived website quality significantly influenced TV, while only perceived website quality had a significant effect on RPI.

Fang et al. (2014) conclude that, while trust is still important, it is less so if consumers perceive that effective e-commerce institutional mechanisms (EIMs) are in place (Fang et al., 2014). Therefore, increasing trust and perceived trustworthiness is insufficient and does not assemble a competitive advantage if EIMs are perceived to be effective. Fang et al. (2014) suggest investing more heavily in promoting trust, when EIMs are perceived as ineffective, compared to environments in which EIMs are perceived as effective. 


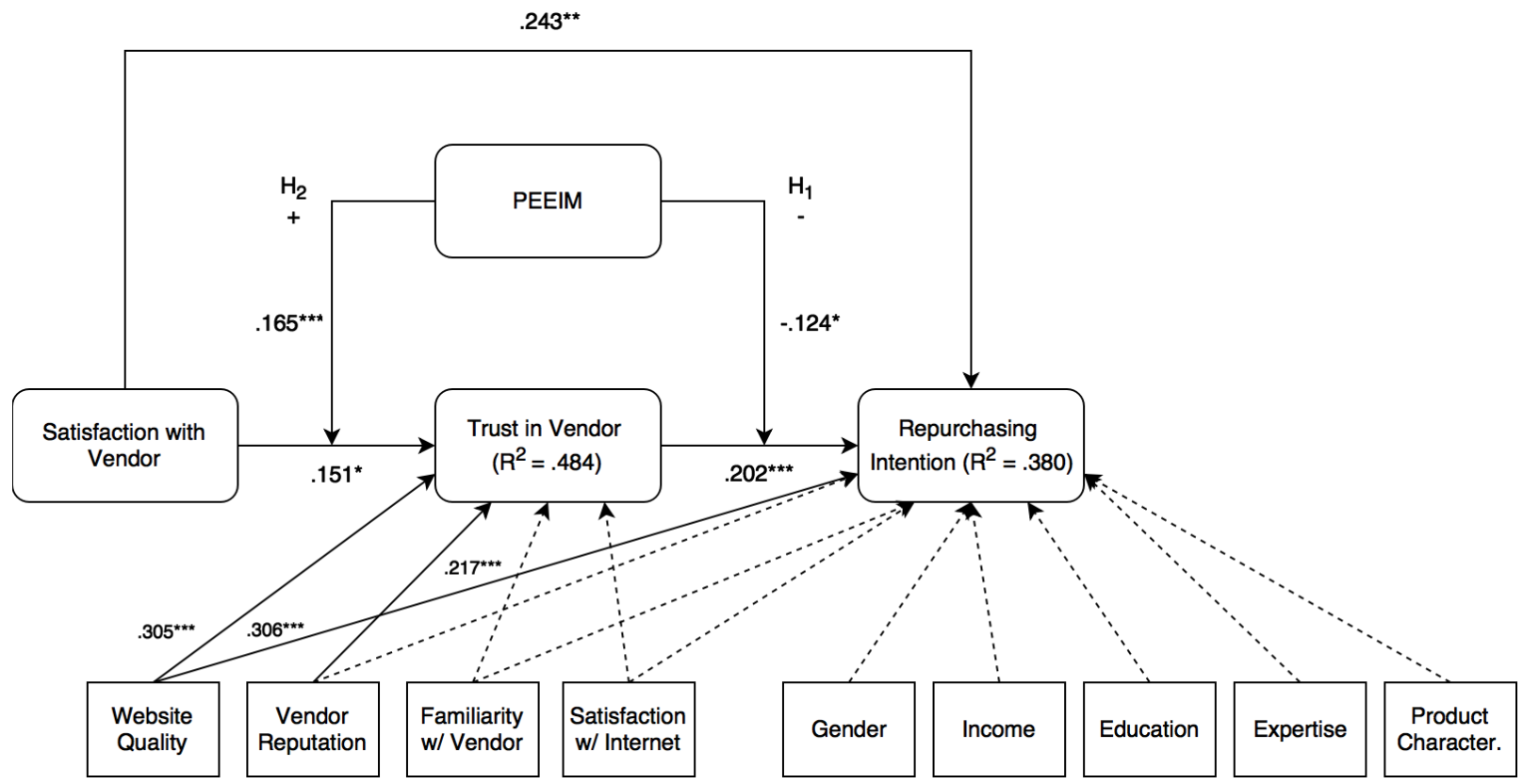

Figure 1. Research Model Results of the Original Study (Fang et al., 2014)

\subsection{Overview of the Replication Study}

Of the three main types of replication studies (Dennis \& Valacich, 2014), we conducted a methodological replication. Therefore, our study used exactly the same methods (i.e., survey design, statistical analyses, etc.) as the original study, which is why the main part of our survey is similar to the original paper (cf. Fang et al., 2014). As the term methodological replication implies, we maintained the methodology but conducted our study in a different context (i.e., Germany vs. Northern Ireland; panel participants vs. students and faculty members). We decided to replicate the original study in Germany because Germany is a market comparable to the Northern Ireland market investigated in the study by Fang et al. (2014). We did not conduct it exclusively among students and university faculty members but broadened our sample by explicitly inviting other (online) consumers as well.

In regard to the model and hypotheses used in this replication study, we retain the model and the hypotheses proposed by Fang et al. (2014). Table 1 gives an overview of the implementation characteristics of both the original study and the replication. In the following section, we describe the research methodology applied to test this model.

\begin{tabular}{|l|l|l|}
\hline \multicolumn{3}{|c|}{ Table 1. Comparison of the Implementation of the Original Study and the Replication. } \\
\hline & Fang et al. (2014) & Replication \\
\hline Sample & $\begin{array}{l}\text { University Personnel and Students, Northern } \\
\text { Ireland }\end{array}$ & Panel Data (SoSci Survey), Germany \\
\hline Data Collection & 2004 (and 2013) & 2016 \\
\hline Sample Size & 362 & 726 \\
\hline Data Analysis Technique & Partial Least Squares (SmartPLS) & Partial Least Squares (SmartPLS) \\
\hline Language & English & German \\
\hline Most Popular & Air Tickets & Clothes and Electronics \\
\hline
\end{tabular}




\section{Research Methodology}

\subsection{Survey Design}

Our survey is divided into two parts. The first part was used to measure the general experience of online shopping. The concepts PEEIM, satisfaction with shopping online and general expertise using the Internet were measured using seven-point Likert scales.

As a break between the first and the second part of the study, a recall method was added. This method was replicated from the original study to subconsciously guide the participants to concentrate on a specific vendor to trigger the recollection of a specific, rather than a general, experience.

The second part of our study included the concepts SV, RPI, TV, vendor reputation, and perceived website quality, which focused on what the vendor remembered during the recall task. All items in the second part were measured through seven-point Likert scales with the exception of two constructs (i.e., vendor reputation and perceived website quality), which were each assessed on seven-point semantic differential scales. In line with the original research, we asked for the price of the product or service bought and its type. Furthermore, demographic variables (i.e., age, gender, education, employment, income, and location) were collected.

We complemented the survey with a control mechanism comparable to previous research (e.g., Gimpel, Nißen, \& Görlitz, 2013) to control for common method variance (Lindell \& Whitney, 2001). For instance, we asked the participants between other items to select a specific value, collected all data anonymously, and did not offer or imply any rewards for specific answers (for further details on our approach to prevent and analyze common method variance, see Limitations).

To validate the translation process, we used the back translation method (Brislin, 1970). This method was necessary, as the language of the original survey was English and our study was conducted in Germany. The translation from English to German was made by a hired professional English native speaker and reviewed by a second, independent one. Afterwards, two German native speakers individually translated the German version back into English. Finally, a third person proof-read the original and the back-translated versions to assure translation quality (Brislin, 1970). Appendix B gives the original, English items in Table B1, while Table B2 gives the translated, German items.

\subsection{Data Collection}

The data was collected through the online survey tool SoSci Survey (http://www.soscisurvey.de) mainly for three reasons. First, the tool allows one to conduct complex surveys easily. Second, our survey was reviewed one additional time to ensure design quality, including formal (questions and expressions) and informal (design and layout) aspects. Therefore, we had to modify the wording of some questions. The third crucial reason for using the tool is that we had the opportunity to obtain access to a panel and therefore access to more participants.

Basically, conducting the survey comprised two phases:

(I) First, we executed a pretest for testing the model in the new context. In contrast to the original study, we did not impose any explicit (e.g., specific age, gender, or occupation) or implicit (e.g., distributing our study during lectures) restrictions in respect to the respondents. To expand the context of the original study, we did not exclude any educational levels or employment statuses. We acquired the respondents for the pretest from our personal networks through broadcasting messages, as well as personal invitations via social media (e.g., Facebook). Additionally, we sent invitations to a Facebook group, which acts as an open panel for scientific survey. Furthermore, we appealed for further distribution by social networks.

(II) After conducting the pretest, we used the panel to gain deeper insights and to increase the sample size. The panel used is provided by SoSci Survey as non-representative, with approximately 93,000 registered subjects.

The survey was tested independently by all authors, as well by three peers. The timeframe of the data collection was set to four weeks each for both the pretest and panel survey. 
Two control questions were added to the questionnaire to inspect the attentiveness of the interviewees while completing the questionnaire. The completed questionnaires with wrong answers to these two questions were excluded from the analysis.

\section{Data Analysis \& Results}

During the pretest, 234 usable responses were gathered. The mean age of our participants is 24.7 years, varying between 19 and 52 years $(S D=5)$. The most common items bought were electronics $(n=51)$, clothes $(n=46)$, books and DVDs $(n=27)$, and sports equipment $(n=24)$. The price of the product or service bought averaged 143 Euros, ranging from 5 to 6,000 Euros (SD $=424$ Euros). As the data analysis from the pre-test did not lead to different conclusions, we only report our findings from the panel survey.

In total, 874 questionnaires were filled out completely by members of the SoSci Panel. SoSci offers quality criteria to clean the data set from dishonest (e.g., click-through participants) or automated (e.g., bots) answers. Penalties are given for below-average complete times (i.e., participants who were faster than the average time of completion) and for missing answers (for more information, see SoSci Survey Help). A total of 939 participants participated in our study. Out of the 874 completed questionnaires, 726 remained because 148 respondents did not answer correctly one or both of our control questions. The mean age of our participants is 39.3 years, varying between 16 and 87 years $(S D=14.5)$. The participants reported an average yearly income of 42,172.82 Euros, ranging between 20.00 and 550,000.00 Euros (SD $=54,010.57$ Euros). Approximately $62.26 \%$ of the participants identified as female $(n=452)$, while $36.36 \%(n=264)$ identified as male and $0.14 \%(n=1)$ identified as other; $1.24 \%(n=9)$ did not answer. Most of the participants ( $n=352 ; 48.485 \%)$ reported being employed, but not at a university, followed by students $(n=169$; $23.278 \%)$, self-employed $(n=58 ; 7.989 \%)$, university personnel $(n=53 ; 7.300 \%)$, retiree $(n=45 ; 6.198 \%)$, and job-seeking $(n=17 ; 2.342 \%)$. Thirty-two $(4.408 \%)$ did not answer. While the majority of participants reported residing in Germany $(n=599 ; 82.507 \%)$, some reported residing in other parts of Europe $(n=118$; $16.253 \%)$ and some elsewhere $(n=7 ; 0.964 \%)$. Two did not answer $(0.275 \%)$. Most of the participants $(n=$ $431 ; 59.367 \%)$ reported having a university degree, followed by a high-school diploma or equivalent $(n=$ $226 ; 31.130 \%)$, secondary school leaving certificate or equivalent $(n=56 ; 7.713 \%)$, and no degree $(n=1$; $0.138 \%)$. Twelve did not answer (1.653\%). The most common items bought were clothes $(n=121)$, electronics $(n=114)$, books $(n=103)$, household items $(n=42)$, sports equipment $(n=34)$, movies $(n=$ 30 ), flight tickets $(n=26)$, and other items $(n=256$, e.g., hotel room bookings, kitchen items, concert tickets, etc.).

In line with the original study, the research model was tested using partial least squares (PLS). For the analysis, we relied on SmartPLS (Ringle, Wende, \& Becker, 2015). The analyses concerning the moderating effects were performed using the product-indicator approach. The significance tests were retrieved using SmartPLS' bootstrapping with 5,000 samples.

\subsection{Measurement Model}

Since our measurement model contains reflective indicators only, we consider the following four criteria for reliability and validity: internal consistency, indicator reliability, convergent validity, and discriminant validity.

First, two criteria can be used to evaluate internal consistency. Cronbach's alpha and composite reliability must exceed 0.700 for each construct (Nunnally, 1978; Werts, Linn, \& Jöreskog, 1974). The model fulfills both criteria since the respective values are above the recommended threshold (see Table 2).

Second, indicators are considered reliable if the associated latent construct explains more than half of the indicator's variance (Henseler, Ringle, \& Sinkovics, 2009). Indicators are reliable if they have a t-value equal to 1.66 or higher (level of significance .05) and a loading of 0.700 or higher. Concerning items with loadings below 0.700, we proceeded as follows (Hair, Hult, Ringle, \& Sarstedt, 2013). Since none of the items had a loading below 0.400 , we assessed whether removing items led to an improvement of composite reliability or average variance extracted (AVE) of the respective latent construct. Beginning with the item with the lowest loading (i.e., WQ10 with a loading of 0.474), we removed the respective item and recalculated the model. As a result, we removed the following items: WQ10, WQ11, WQ13, WQ09, WQ06, TV04, SV03, and SI03. Notwithstanding the removal, we retained sufficient items for each construct. We explain the removal of the set of items for website quality in our discussion. 
Table 2. Mean, Standard Deviation (SD), Cronbach's Alpha (CA), Composite Reliability (CR), Average Variance Extracted (AVE), Construct Correlations, and the Square Root of AVE

\begin{tabular}{|c|c|c|c|c|c|c|c|c|c|c|c|c|c|c|c|}
\hline & $\begin{array}{l}\stackrel{ᄃ}{\mathbb{ల}} \\
\sum\end{array}$ & ம) & ठ & 寽 & $\underset{\longleftarrow}{\rightleftarrows}$ & $\bar{\omega}$ & $\stackrel{\Upsilon}{\lessgtr}$ & $\begin{array}{l}\bar{\alpha} \\
\bar{x}\end{array}$ & $\underset{\underset{u}{W}}{\stackrel{\sum}{W}}$ & $\gtrless$ & ळ & $\stackrel{0}{3}$ & 品 & $\vec{\amalg}$ & ৫ \\
\hline SI & 5.605 & 1.164 & .855 & .932 & .873 & .934 & & & & & & & & & \\
\hline VR & 5.190 & 1.296 & .873 & .940 & .887 & .159 & .942 & & & & & & & & \\
\hline RPI & * & * & .895 & .935 & .827 & .364 & .138 & .909 & & & & & & & \\
\hline PEEIM & 3.350 & 1.673 & .782 & .858 & .604 & .383 & .152 & .143 & .777 & & & & & & \\
\hline TV & 5.424 & 1.342 & .903 & .924 & .635 & .427 & .473 & .417 & .341 & .797 & & & & & \\
\hline SV & 6.007 & 1.207 & .913 & .945 & .852 & .505 & .433 & .603 & .239 & .740 & .923 & & & & \\
\hline WQ & 5.704 & 1.227 & .896 & .917 & .579 & .287 & .279 & .425 & .145 & .419 & .466 & .761 & & & \\
\hline EXP & 5.665 & 1267 & .886 & .921 & .746 & .367 & .054 & .258 & .233 & .283 & .279 & .219 & .864 & & \\
\hline FV & 5.530 & 1.320 & 1.00 & 1.00 & 1.00 & .269 & .186 & .529 & .180 & .415 & .454 & .371 & .358 & 1.00 & \\
\hline$G$ & ** & ** & 1.00 & 1.00 & 1.00 & -.010 & -.055 & -.030 & -.015 & .000 & -.048 & -.092 & . 101 & .024 & 1.00 \\
\hline \multicolumn{16}{|c|}{ diagonal elements represent the square-root of $\mathrm{AVE}$} \\
\hline \multicolumn{16}{|c|}{ * due to different scales of each item, no mean and standard deviation are available } \\
\hline
\end{tabular}

Third, the following criteria can be applied to assess convergent validity (Fornell \& Larcker, 1981): composite construct reliabilities should exceed 0.800 and AVE should exceed 0.500 for each construct. Table 2 demonstrates that the composite reliabilities of all constructs exceed the required minimum of 0.800 and that the AVE values of all constructs exceed the threshold of 0.500 . Thus, convergent validity conditions are met.

Fourth, to confirm discriminant validity, latent variables must explain their indicators' variances to a higher degree than the variances of other latent variables (Fornell \& Larcker, 1981). Accordingly, the square root of each construct's AVE must exceed the correlations with the other constructs. With the highest correlation between two constructs of 0.740 and the lowest square root of an AVE of .761, all latent variables fulfill this criterion (see Table 2). Moreover, we evaluated discriminant validity by examining the factor loadings of each indicator. According to Chin (1998), each indicator must load higher on the associated construct compared to all other factors. In our case, corroborate discriminant validity is confirmed by factor loadings and cross-loadings (see Table 3). In addition to the Fornell-Larcker criterion, Henseler, Ringle, and Sarstedt (2015) propose Heterotrait-monotrait (HTMT) ratio of correlations as a new criterion to assess discriminant validity. Table 4 shows the calculated HTMT values for our model. The highest HTMT value of 0.809 is below a conservative threshold of 0.850 (Henseler et al., 2015). Combining the results from the HTMT criterion and the Fornell-Larcker criterion is seen as a promising approach to assess discriminant validity (Voorhees, Brady, Calantone, \& Ramirez, 2015).

\begin{tabular}{|l|c|c|c|c|c|c|c|c|c|c|c|}
\hline \multicolumn{10}{|c|}{ Table 3. Factor Loadings (bold) and Cross-loadings } \\
\hline Construct & Item & SI & VR & RPI & PEEIM & TV & SV & WQ & EXP & FV & G \\
\hline $\begin{array}{l}\text { Satisfaction w/ Internet } \\
\text { (SI) }\end{array}$ & SI01 & .933 & .161 & .338 & .335 & .395 & .474 & .296 & .319 & .243 & -.025 \\
\cline { 2 - 12 } & SI02 & .936 & .136 & .343 & .381 & .403 & .470 & .242 & .367 & .259 & .005 \\
\hline $\begin{array}{l}\text { Vendor Reputation } \\
\text { (VR) }\end{array}$ & VR01 & .128 & .934 & .110 & .139 & .418 & .370 & .251 & .042 & .160 & -.053 \\
\cline { 2 - 11 } & VR02 & .169 & .950 & .147 & .147 & .470 & .441 & .273 & .058 & .188 & -.050 \\
\hline $\begin{array}{l}\text { Repurchase Intention } \\
\text { (RPI) }\end{array}$ & RP01 & .317 & .074 & .876 & .132 & .307 & .474 & .389 & .247 & .488 & .024 \\
\cline { 2 - 10 } & RP02 & .356 & .171 & .911 & .141 & .414 & .582 & .375 & .224 & .460 & -.051 \\
\hline
\end{tabular}




\begin{tabular}{|c|c|c|c|c|c|c|c|c|c|c|c|}
\hline \multicolumn{12}{|c|}{ Table 3. Factor Loadings (bold) and Cross-loadings } \\
\hline & RP03 & .321 & .127 & .940 & .119 & .411 & .586 & .396 & .235 & .496 & -.051 \\
\hline \multirow[t]{4}{*}{ PEEIM } & PE01 & .326 & .096 & .087 & .824 & .260 & .167 & .081 & .159 & .120 & -.027 \\
\hline & PE02 & .370 & .186 & .164 & .824 & .320 & .246 & .153 & .268 & .183 & -.047 \\
\hline & PE03 & .256 & .068 & .090 & .753 & .252 & .154 & .102 & .151 & .128 & 3.002 \\
\hline & PE04 & .208 & .099 & .085 & .700 & .207 & .158 & .104 & .111 & .114 & .047 \\
\hline \multirow{7}{*}{$\begin{array}{l}\text { Trust in Vendor } \\
\text { (TV) }\end{array}$} & TV01 & .322 & .319 & .257 & .226 & .714 & .510 & .285 & .203 & \begin{tabular}{|l|}
.279 \\
\end{tabular} & .026 \\
\hline & TV02 & .345 & .298 & .428 & .265 & .774 & .631 & .414 & .234 & .384 & -.005 \\
\hline & \begin{tabular}{|l|} 
TV03 \\
\end{tabular} & .311 & .438 & .268 & .305 & .830 & .562 & .295 & .223 & .295 & \begin{tabular}{|l|}
.048 \\
\end{tabular} \\
\hline & TV05 & \begin{tabular}{|l|}
.317 \\
\end{tabular} & .357 & .263 & .353 & .735 & .493 & .332 & .201 & .304 & $\begin{array}{l}-.062 \\
\end{array}$ \\
\hline & \begin{tabular}{|l|} 
TV06 \\
\end{tabular} & .373 & .414 & .357 & .295 & .864 & .644 & .327 & .259 & .341 & -.032 \\
\hline & \begin{tabular}{|l|} 
TV07 \\
\end{tabular} & .288 & .484 & .303 & .254 & .823 & .590 & .315 & .205 & .327 & .022 \\
\hline & TV08 & .414 & .338 & .411 & .218 & .828 & .667 & .355 & .246 & .368 & 3.006 \\
\hline \multirow{3}{*}{$\begin{array}{l}\text { Satisfaction w/ Vendor } \\
\text { (SV) }\end{array}$} & SV01 & \begin{tabular}{|l|}
.497 \\
\end{tabular} & .353 & .564 & .204 & .709 & .940 & .448 & .257 & .409 & -.043 \\
\hline & \begin{tabular}{|l|} 
SV02 \\
\end{tabular} & .494 & .416 & .551 & .233 & .713 & .943 & .459 & .254 & .435 & \begin{tabular}{|l|l|} 
\\
\end{tabular} \\
\hline & SV04 & .404 & .434 & .557 & .227 & .625 & .885 & .380 & .264 & .413 & \begin{tabular}{|l|l|} 
& -.065 \\
\end{tabular} \\
\hline \multirow{8}{*}{$\begin{array}{l}\text { Website Quality } \\
\text { (WQ) }\end{array}$} & WQ01 & .251 & .212 & .364 & .087 & .324 & .389 & .826 & .157 & .305 & -.121 \\
\hline & WQ02 & .228 & .254 & .342 & .112 & .406 & .410 & .793 & .163 & .310 & -.069 \\
\hline & WQ03 & .199 & .224 & .276 & .113 & .292 & .333 & .796 & .174 & .247 & $\begin{array}{ll}-.092 \\
\end{array}$ \\
\hline & WQ04 & .206 & .244 & .288 & .125 & .326 & .349 & .768 & .157 & .276 & -.081 \\
\hline & WQ05 & .265 & .147 & .357 & .116 & .236 & .318 & .721 & .202 & .291 & \begin{tabular}{|l|}
.024 \\
\end{tabular} \\
\hline & WQ07 & .251 & .152 & .371 & .082 & .279 & .342 & .708 & .242 & .312 & -.007 \\
\hline & WQ08 & .199 & .229 & .294 & .140 & .335 & .341 & .716 & .137 & .249 & -.091 \\
\hline & WQ12 & .142 & .226 & .280 & .115 & .331 & .335 & .750 & .101 & .256 & $\begin{array}{ll}.073 \\
\end{array}$ \\
\hline \multirow{4}{*}{$\begin{array}{l}\text { Expertise } \\
(E X P)\end{array}$} & EX01 & .343 & .076 & .266 & .259 & .263 & .249 & .222 & .920 & .347 & .100 \\
\hline & EX02 & .338 & .026 & .236 & .141 & .239 & .273 & .188 & .838 & 309 & .014 \\
\hline & EX03 & .278 & .011 & .191 & .182 & .214 & .203 & .151 & .818 & .273 & .124 \\
\hline & EX04 & .297 & .067 & .177 & .218 & .258 & .232 & .185 & .875 & .295 & .128 \\
\hline Familiarity w/ Vendor (FV) & FV01 & .269 & .186 & .529 & .180 & .415 & .454 & .371 & .358 & 1.00 & .024 \\
\hline Gender $(G)$ & G01 & -.010 & -.055 & -.030 & -.015 & .000 & -.048 & -.092 & .101 & .024 & 1.00 \\
\hline
\end{tabular}

\begin{tabular}{|l|c|c|c|c|c|c|c|c|c|c|}
\hline \multicolumn{10}{|c|}{ Table 4. HTMT Values } \\
\hline Construct & SI & VR & RPI & PEEIM & TV & SV & WQ & EXP & FV & G \\
\hline SI & -- & & & & & & & & & \\
\hline VR & .182 & -- & & & & & & & & \\
\hline RPI & .417 & .153 & -- & & & & & & & \\
\hline PEEIM & .456 & .175 & .164 & -- & & & & & & \\
\hline TV & .484 & .533 & .401 & .401 & -- & & & & & \\
\hline SV & .571 & .484 & .276 & .276 & .809 & -- & & & & \\
\hline WQ & .327 & .313 & .170 & .170 & .460 & .511 & -- & & & \\
\hline EXP & .417 & .059 & .284 & .264 & .314 & .308 & .243 & -- & & \\
\hline FV & .291 & .198 & .560 & .198 & .434 & .475 & .390 & .376 & -- & \\
\hline G & .017 & .059 & .049 & .044 & .038 & .051 & .097 & .113 & .024 & -- \\
\hline
\end{tabular}




\subsection{Structural Model}

Figure 2 displays the structural model with standardized weights and indicates significant $p$-values, while Table 5 provides the respective values for effect size $\left(f^{2}\right)$ and predictive relevance $\left(q^{2}\right)$. The two main hypotheses of Fang et al. (2014) were a negative moderation of PEEIM on the relation between TV and RPI $\left(\mathrm{H}_{1}\right)$ and that PEEIM positively moderates the relationship between SV and TV $\left(\mathrm{H}_{2}\right)$. Figure 2 shows that PEEIM has no moderating effect on the relation between TV and RPI $(p=n$.s.) for our sample and that PEEIM also has no moderating effect on the relation between SV and TV $(p=n$.s.). Furthermore, TV has no significant direct effect on RPI ( $p=n$.s.). In contrast, the connection between SV and RPI $(p<.001)$ is highly significant. The remaining paths, that is, SV to TV $(p<.001)$ and PEEIM to TV $(p<.001)$, were found to be highly significant. These results are contrary to the original study by Fang et al. (2014), as our results do not support $\mathrm{H}_{1}$ and $\mathrm{H}_{2}$. Instead, our results indicate that there is a significant influence of PEEIM on TV $(p<.001)$.

Figure 2 also includes the control variables, whereby dotted lines represent non-significant paths (i.e., with a p-value $>=.05$ ) and solid lines represent significant paths. While the paths from website quality to RPI and TV as well as the path from vendor reputation to TV, were significant in both the original study and our replication, our replication showed vendor reputation to have a significant effect on TV, which was not present in the original study. Further, familiarity with vendor was a significant predictor for RPI and TV in our study, which contradicts the findings of Fang et al. (2014).

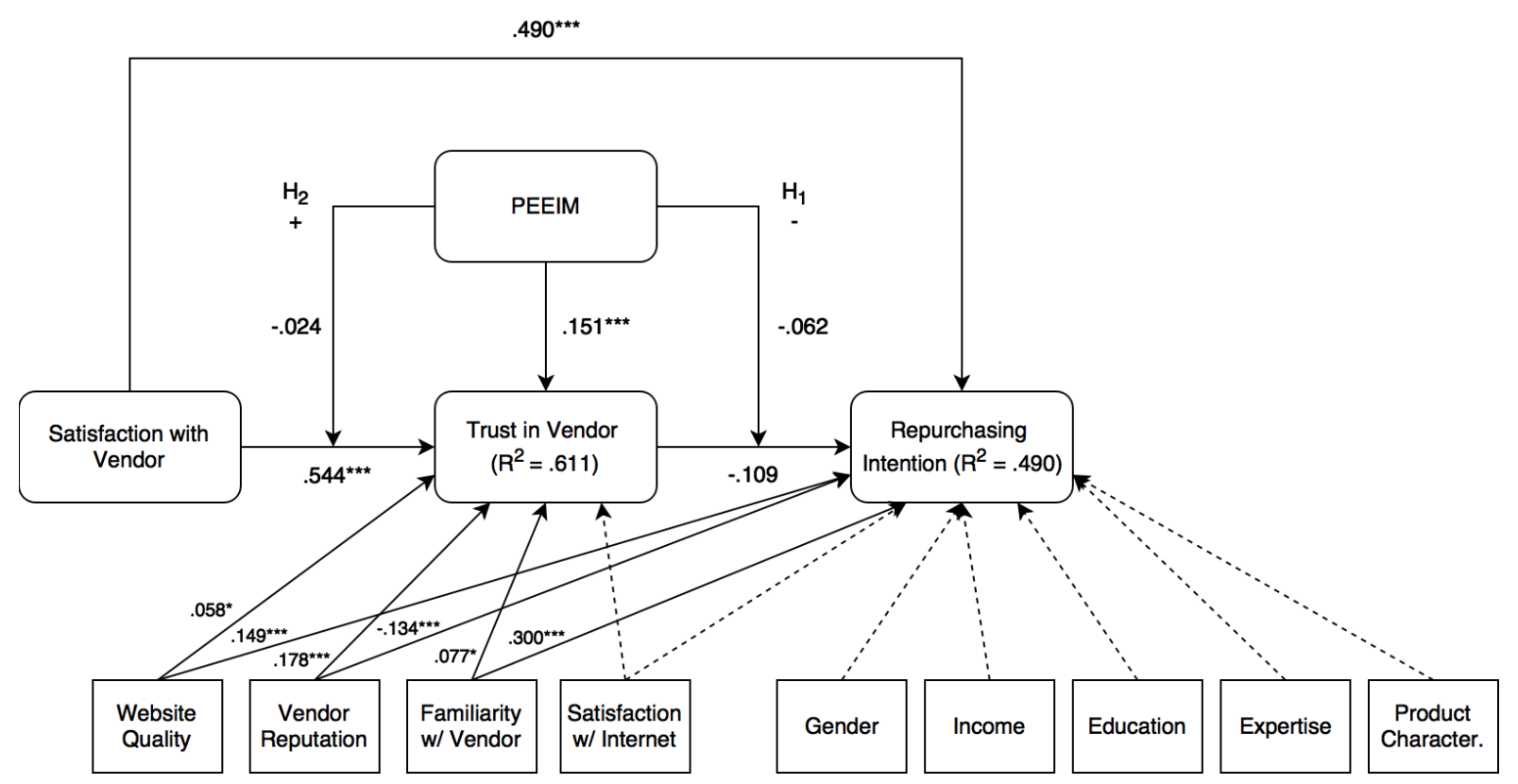

Figure 2. Estimated Research Model

${ }^{*}: p<.05 ;{ }^{* *}: p<.01 ;{ }^{* * *}: p<.001$

\begin{tabular}{|l|c|c|c|c|}
\hline \multicolumn{4}{|c|}{ Table 5. Effect Size and Predictive Relevance } \\
\hline \multirow{2}{*}{} & \multicolumn{2}{|c|}{$\mathbf{f}^{2}$} & $\begin{array}{c}\text { Effect Size according } \\
\text { to Cohen (1988) }\end{array}$ & $\mathbf{q}^{2}$ \\
\cline { 2 - 5 } & \multicolumn{2}{|c|}{ Original } & \multicolumn{2}{c|}{ Replication } \\
\hline $\mathrm{SV} \rightarrow \mathrm{TV}$ & .010 & .349 & medium to high & .142 \\
\hline $\mathrm{SV} \rightarrow \mathrm{RPI}$ & -- & .165 & medium & .107 \\
\hline $\mathrm{TV} \rightarrow \mathrm{RPI}$ & 0.12 & .009 & small & .003 \\
\hline $\mathrm{PEEIM} \rightarrow \mathrm{TV}$ & -- & .049 & small & .017 \\
\hline $\mathrm{SV} *$ PEEIM $\rightarrow \mathrm{TV}$ & .050 & .001 & small & .000 \\
\hline $\mathrm{TV} *$ PEEIM $\rightarrow \mathrm{RPI}$ & .003 & .007 & small & .002 \\
\hline
\end{tabular}




\section{Discussion}

\subsection{Implications}

Table 6 juxtaposes the findings of the original study (Fang et al., 2014) and our replication for the measurement model, the structural model, and the control variables. While relying on a methodological replication (i.e., using the same methods but in a different context), our main finding is the lack of support for the model of Fang et al. (2014). In particular, our study neither supports $\mathrm{H}_{1}$ (i.e., PEEIM's moderating role for TV $\rightarrow \mathrm{RPI}$ ) nor $\mathrm{H}_{2}$ (i.e., PEEIM's moderating role for $\mathrm{SV} \rightarrow \mathrm{TV}$ ). Instead, we identified a positive influence of PEEIM on TV, which was not revealed in the study by Fang et al. (2014). Additionally, our replication does not confirm the positive influence of TV on RPI. In the following, we discuss reasons for these contradicting findings and suggest avenues for future research. The larger sample size of 726 usable responses in our study, compared to the original study, which had 362 usable responses (Fang et al., 2014), is generally favorable to increase the representativeness of the research. However, it also likely to contribute to the significance of the control variables and path weights.

\begin{tabular}{|c|c|c|}
\hline & Fang et al. (2014) & Replication \\
\hline \multicolumn{3}{|c|}{ Measurement Model } \\
\hline Model Fit \& Evaluation & Satisfactory & Satisfactory (after item removal) \\
\hline \multicolumn{3}{|c|}{ Structural Model } \\
\hline $\mathrm{TV} \rightarrow \mathrm{RPI}$ & Significant & Non-Significant \\
\hline SAT $\rightarrow$ TV & Significant & Significant \\
\hline $\mathrm{SAT} \rightarrow \mathrm{RPI}$ & Significant & Significant \\
\hline PEEIM $\rightarrow$ TV & Non-Significant & Significant (consistent with Pavlou \& Gefen, 2004) \\
\hline $\mathrm{PEEIM} \rightarrow \mathrm{RPI}$ & Non-Significant & Non-Significant \\
\hline $\mathrm{H}_{1}:$ PEEIM * SAT $\rightarrow$ TV & Significant & Non-Significant \\
\hline $\mathrm{H}_{2}: \mathrm{PEEIM}$ * TV $\rightarrow \mathrm{RPI}$ & Significant & Non-Significant \\
\hline \multicolumn{3}{|c|}{ Control Variables } \\
\hline Perceived Website Quality $\rightarrow$ TV & Significant & Non-Significant \\
\hline Perceived Website Quality $\rightarrow$ RPI & Significant & Significant \\
\hline Vendor Reputation $\rightarrow$ TV & Significant & Significant \\
\hline Vendor Reputation $\rightarrow$ RPI & Non-Significant & Significant \\
\hline Familiarity $\mathrm{w} /$ Vendor $\rightarrow$ TV & Non-Significant & Significant \\
\hline Familiarity w/Vendor $\rightarrow$ RPI & Non-Significant & Significant \\
\hline Gender $\rightarrow$ RPI & Non-Significant & Significant \\
\hline Satisfaction w/ Internet $\rightarrow$ TV & Non-Significant & Non-Significant \\
\hline Satisfaction w/ Internet $\rightarrow$ RPI & Non-Significant & Non-Significant \\
\hline Income $\rightarrow$ RPI & Non-Significant & Non-Significant \\
\hline Education $\rightarrow$ RPI & Non-Significant & Non-Significant \\
\hline Expertise $\rightarrow \mathrm{RPI}$ & Non-Significant & Non-Significant \\
\hline Product Characteristics $\rightarrow \mathrm{RPI}$ & Non-Significant & Non-Significant \\
\hline
\end{tabular}

In general, we see a major reason for the observed differences in the point in time at which the data was collected for the original study and our replication. While we collected data in 2016, the data in the original study was predominantly collected in approximately 2004 . Given the time that has elapsed between both studies, several contextual factors have changed. 
First, dynamics of online shopping (e.g., increasing number of online shoppers, advances in mobile technologies and its adoption, new service delivery features) have considerably changed online shoppers' expectations (e.g., design, ease of use, accessibility) concerning websites (Bilgihan, Kandampully, \& Zhang, 2016; Fang, Wen, George, \& Prybutok, 2016). This also becomes apparent in our data. For example, considering the construct website quality, we had to remove several items due to their low loadings that concern aspects such as layout, excitement, and website transmission. The need to adapt the measurement is reflected by more recent approaches to assess website quality (e.g., Wells, Valacich, \& Hess, 2011). The remaining items reflect a focus on websites that are easy to use, well-organized, and provide operational efficiency. While in the early years of e-commerce, aspects such as arousal and excitement might have been important in attracting online shoppers, currently e-commerce websites are well-known and a quasistandard for shoppers; therefore, an effective and efficient order process seems to be the number one priority.

Second, currently, trust in vendor seems to play a minor role in repurchase intentions. In contrast to Fang et al. (2014), our replication does not provide evidence for a positive relation between TV and RPI. While earlier studies are in favor of the role of trust for purchase intensions (e.g., van der Heijden, Verhagen, \& Creemers, 2003), we suggest that trust is important for initially using a website for (online) shopping. However, our results suggest that SV has a medium effect on RPI and is thus more important than trust. In other words, TV is important for the initial contact, while SV is decisive for RPI. Considering the low share of booking a holiday via online channels in the UK at the time of the original study (Statista, 2017b) - which almost doubled from $23 \%$ in 2005 to $44 \%$ in 2013 - and the emphasis on flight tickets in the original sample, a high share of first-time bookers appears likely, for which TV could be important. Furthermore, in today's e-commerce environment, many vendors have been active for more than a decade and have thus acquired a reputation, which they might not have had at the time of the original study. This might have led to a higher importance of institutional mechanisms in the past compared to today's e-commerce, where SV has become a more important factor.

Third, despite the reduced importance of PEEIM in general, it also plays a role here. PEEIM has a positive impact on TV, which did not find support in the original study. Considering that the original study is based on data from an earlier "age" of e-commerce, long-term satisfaction might not have been established yet, thus explaining the larger role of TV at that time. Additionally, our measurement shows that SV and TV are highly correlated. If online shoppers do not explicitly differentiate between the two constructs, it is likely that one of those constructs is mediated by the other. However, the finding that trust and satisfaction concerning a shopping website are highly correlated is not a new one (Yoon, 2002).

Fourth, as online shopping continues to gain importance in Germany - with numbers increasing from 15\% of all shoppers in 2002 to 45\% of all shoppers in 2013 (Statista, 2017c) - online shopping regulations also increase, which leads to better consumer protection and customer rights (Kariyawasam \& Wigley, 2017). Additionally, a majority of respondents in our sample referred to online shopping at Amazon (http://www.amazon.de). In Germany, this vendor has a well-established standing and provides high customer service, which is reflected in Amazon's huge share in Germany's online trading turnover (Statista, 2017a). Trust is, therefore, of less importance if the customers are continuously satisfied with their purchases, which is reflected in our data (i.e., the mean value of SV amounts to 6.007).

Fifth, another difference between the original study and our replication is the kind of purchase made (services vs. goods). Participants of our sample did not mostly buy flight tickets (3.59\% of all items bought in our sample vs. $25.41 \%$ in the original study) but rather electronics $(15.75 \%$, no exact figure available for the original study) and clothing (16.71\% vs. $10.22 \%$ in the original study). Research (e.g., Murray \& Schlacter, 1990) found that services increase the perception of risks compared to goods. Considering the role of TV, one might thus presume that a consumer's process of repurchase differs in regard to goods and services. To analyze this difference, we performed a multi-group analysis (see Appendix C). While Figure $\mathrm{C} 1$ shows the differences between goods and services, Figure C2 and Figure C3 show the estimated path models for goods and services, respectively. Additionally, Table $\mathrm{C} 1$ provides the path weights and p-values for each path. Although Figure $\mathrm{C} 1$ shows no significant differences between goods and services, the estimated path model for services (see Figure C3) reveals a significantly negative moderating effect of PEEIM for the influence of TV on RPI, as suggested in $\mathrm{H}_{1}$. However, the moderated path - that is, the effect of TV on RPI - remains non-significant.

Based on these implications, we suggest the following avenues for future research. First, the analysis should include further contextual control variables. Predominantly, the differentiation between first purchases and repeated purchases can contribute to better understanding the role of trust for repurchase intentions. 
Second, replicating the study in different cultural settings might reveal further insights. In prior research, cultural differences between people from different countries and regions have been identified based on cultural norms (Hofstede \& Hofstede, 2005), taking into account dimensions such as power distance, individualism, or uncertainty avoidance. For example, as regards uncertainty avoidance Asian cultures such as the Chinese one is much more comfortable with ambiguity und uncertainty than European cultures such the German one (https://www.hofstede-insights.com/country-comparison/china,germany/). Both the original study and our replication were conducted in Western European countries (i.e., in similar contexts). Shifting the analysis, for instance, to Asian cultures is a promising research endeavor in order to test for boundaries as regards the role of PEEIM, which might be different considering the different nature of Western online platforms versus Asian platforms such as TaoBao (e.g., Huang, Chen, Ou, Davison, \& Hua, 2017). Third, in addition to considering different cultural patterns, analyzing repurchase intentions in relation to platforms such as TaoBao can help to explore PEEIM boundaries since it operates in a customer-to-customer context. Here, the interplay of satisfaction, trust, and repurchase intention might be different because the ecommerce institutional mechanisms are not offered by the same party that sells a good or service. Fourth, our multi-group analysis points toward another promising avenue for future research. A more detailed differentiation between different types of purchases can help to determine the boundaries of the research model. Finally, we suggest that further replications should consider a longitudinal design. An analysis of multiple events could reveal differences in buyers' perceptions over repeated purchases, if, for instance, reciprocal causations are the underlying phenomena (Mitchell \& James, 2001). Taking the effects of time and "when the variables involved in the relationship occur" (Mitchell \& James, 2001, p. 530) into consideration is crucial for building better theories.

\subsection{Limitations}

First, our study suffers from limited representativeness since we obtained data from a panel. Due to limited insights into the members of the panel and the panel's acquisition of participants for our study, our data collection is subject to a selection bias. As seen from the descriptive data analysis, our sample is not representative. However, it provides a broad cross-section of different educational backgrounds, age groups, employment statuses, and income levels (see "Data Analysis \& Results" for more details). Recent research investigated how student samples, consumer panels, and online crowdsourcing markets (e.g., Amazon Mechanical Turk) differ in statistical conclusions and found no significant variation when comparing samples originating from the same country (Steelman, Hammer, \& Limayem, 2014). The questionnaire that we used in the panel has a slightly different wording compared to the initial wording resulting from the backtranslation method, as modifications were mandatory for panel access. ${ }^{1}$ Therefore, they are not identical and must be analyzed separately. Strictly speaking, the changes made for panel access affects the comparability of our study to the original study. Bringing these changes into context, we believe that all changes improved the questionnaire's readability and reduced ambiguity.

Second, common method variance might be an issue in our research. While method biases are presumed to be less serious in information systems research compared to other disciplines (Malhotra, Kim, \& Patil, 2006), we designed our study in a way that reduces the risk of increased correlations (Lindell \& Whitney, 2001; Malhotra et al., 2006) that results from collecting information for both the dependent and independent variables from the same key informants. In particular, we included the variables WQ14 and TV9, which requested the respondents to select the option to the far left and right, respectively, and excluded all respondents from our sample who did not comply with one or both of these requests. Additionally, we analyzed our data based on Harmon's single-factor test (Malhotra et al., 2006) by means of an exploratory factor analysis of all items (Podsakoff, Mackenzie, Lee, \& Podsakoff, 2003). With none of the factors accounting for a majority of the variance, common method variance is unlikely to exist in our study. Furthermore, we applied the marker-variable technique in a post hoc fashion to check for the correlation between theoretically uncorrelated dimensions (Malhotra et al., 2006). Using the second-smallest positive correlation (i.e., 0.01) between manifest variables (except for WQ14 and TV9) as proxy (Lindell \& Whitney, 2001) supports the claim that common method variance is not prevalent in our study.

Finally, among all participants, we raffled a 100-Euro voucher for online shopping. To avoid hypothesis guessing as a potential threat to construct validity (Cook \& Campbell, 1979), we did not mention the online

\footnotetext{
${ }^{1}$ As an example, we had to first introduce the question, followed by the scale. For instance, "Please select the option that best describes how satisfied you are with previous experiences with the vendor" became "In the following you will see multiple items regarding your satisfaction of previous experiences with the vendor. Please select the option that fits best".
} 
shop or website and did our best to formulate the lottery as neutrally as possible. Nevertheless, interviewees could have guessed that it was a voucher for Amazon Germany, as these vouchers are common in online surveys. This could have biased the interviewees to mistake Amazon for their last e-commerce vendor, which would result in a non-representative sample in terms of all available e-commerce vendors. The underlying assumptions of how transactions are evaluated and a repurchase intention is formed should nevertheless be comparable, irrespective of the specific vendor.

\section{Conclusion}

With this research, we answer the call for more replication in the field of information systems in general (Dennis \& Valacich, 2014; Morrison et al., 2010; Niederman \& March, 2015) and for the original study of our replication (Fang et al., 2014) in particular. With our methodological replication, we reveal that PEEIM currently does not play a moderating role in the relations between SV, TV, and RPI. By discussing this contradiction based on changes in online shopping behavior between 2004 and 2016, we contribute to an improved understanding of the mechanisms in online shopping contexts. 


\section{References}

Bilgihan, A., Kandampully, J., \& Zhang, T. (2016). Towards a unified customer experience in online shopping environments. antecedents and outcomes. International Journal of Quality and Service Sciences, 8(1), 102-119.

Brislin, R. W. (1970). Back-translation for cross-cultural research. Journal of Cross-Cultural Psychology, 1(3), 185-216.

Chin, W. W. (1998). The partial least squares approach to structural equation modeling. In G. A. Marcoulides (Ed.), Modern methods for business research (pp. 295-358). Mahwah: Erlbaum.

Cohen, J. W. (1988). Statistical Power Analysis for the Behavioral Sciences (2 ${ }^{\text {nd }}$ ed.). Hillsdale: Erlbaum.

Cook, T. D., \& Campbell, D. T. (1979). Quasi-experimentation: Design and Analysis Issues for Field Settings. Boston: Cengage Learning.

Dennis, A. R., \& Valacich, J. S. (2014). A replication manifesto. AIS Transactions on Replication Research, $1(1), 1$.

Fang, J., Wen, C., George, B., \& Prybutok, V. R. (2016). Consumer heterogeneity, perceived value, and repurchase decision-making in online shopping: The role of gender, age, and shopping motives. Journal of Electronic Commerce Research, 17(2), 116-131.

Fang, Y., Qureshi, I., Sun, H., McCole, P., Ramsey, E., \& Lim, K. H. (2014). Trust, satisfaction, and online repurchase intention: The moderating role of perceived effectiveness of e-commerce institutional mechanisms. MIS Quarterly, 38(2), 407-427.

Flavián, C., Guinalíu, M., \& Gurrea, R. (2006). The role played by perceived usability, satisfaction and consumer trust on website loyalty. Information \& Management, 43(1), 1-14.

Fornell, C., \& Larcker, D. F. (1981). Evaluating structural equation models with unobservable variables and measurement error. Journal of Marketing Research, 18(1), 39-50.

Gefen, D. (2002). Customer loyalty in e-commerce. Journal of the Association for Information Systems, 3(1), 2.

Gefen, D., Benbasat, I., \& Pavlou, P. (2008). A research agenda for trust in online environments. Journal of Management Information Systems, 24(4), 275-286.

Gimpel, H., Nißen, M., \& Görlitz, R. (2013). Quantifying the quantified self: A study on the motivations of patients to track their own health.

Hair, J. F., Jr., Hult, G. T. M., Ringle, C. M., \& Sarstedt, M. (2013). A Primer on Partial Least Squares Structural Equation Modeling (PLS-SEM). Los Angeles: Sage.

Henseler, J., Ringle, C. M., \& Sarstedt, M. (2015). A new criterion for assessing discriminant validity in variance-based structural equation modeling. Journal of the Academy of Marketing Science, 43(1), 115-135.

Henseler, J., Ringle, C. M., \& Sinkovics, R. R. (2009). The use of partial least squares path modeling in international marketing. Advances in International Marketing, 20(IV), 277-319.

Hofstede, G., \& Hofstede, G. J. (2005). Cultures and Organizations: Software of the Mind. McGraw-Hill, New York.

Huang, Q., Chen, X., Ou, C. X., Davison, R. M., \& Hua, Z. (2017). Understanding buyers' loyalty to a C2C platform: The roles of social capital, satisfaction and perceived effectiveness of e-commerce institutional mechanisms. Information Systems Journal, 27(1), 91-119.

Johnson, C., Hult, P., \& McGowan, B. (2008). Web buyers - and their expectations - grow up. Retrieved from https://www.forrester.com/report/Web+Buyers+And+Their+Expectations+Grow+Up/-/E$\underline{R E S 45462}$

Kariyawasam, K., \& Wigley, S. (2017). Online shopping, misleading advertising and consumer protection. Information \& Communications Technology Law, 26(2), 73-89. 
Lindell, M. K., \& Whitney, D. J. (2001). Accounting for common method variance in cross-sectional research designs. Journal of Applied Psychology, 86(1), 114-121.

Lindsay, D. S. (2015). Replication in psychological science. Psychological Science, 0956797615616374.

Malhotra, N. K., Kim, S. S., \& Patil, A. (2006). Common method variance in IS research: A comparison of alternative approaches and a reanalysis of past research. Management Science, 52(12), 18651883.

McKnight, D. H., Cummings, L. L., \& Chervany, N. L. (1998). Initial trust formation in new organizational relationships. Academy of Management Review, 23(3), 473-490.

Mitchell, T. R., \& James, L. R. (2001). Building better theory: Time and the specification of when things happen. The Academy of Management Review, 26(4), 530-547.

Morrison, R., Matuszek, T., \& Self, D. (2010). Preparing a replication or update study in the business disciplines. European Journal of Scientific Research, 47(2), 278-287.

Murray, K. B., \& Schlacter, J. L. (1990). The impact of services versus goods on consumers' assessment of perceived risk and variability. Journal of the Academy of Marketing Science, 18(1), 51-65.

Niederman, F., \& March, S. (2015). Reflections on replications. AIS Transactions on Replication Research, $1(1), 7$.

Nunnally, J. C. (1978). Psychometric Theory (2nd ed.). New York: McGraw-Hill.

Pavlou, P. A., \& Gefen, D. (2004). Building effective online marketplaces with institution-based trust. Information Systems Research, 15(1), 37-59.

Podsakoff, P. M., Mackenzie, S. B., Lee, J.-Y., \& Podsakoff, N. P. (2003). Common method biases in behavioral research: A critical review of the literature and recommended remedies. Journal of Applied Psychology, 88(5), 879-903.

Popper, K. (2005). The Logic of Scientific Discovery: Routledge.

Qureshi, I., Fang, Y., Ramsey, E., McCole, P., Ibbotson, P., \& Compeau, D. (2009). Understanding online customer repurchasing intention and the mediating role of trust - An empirical investigation in two developed countries. European Journal of Information Systems, 18(3), 205-222.

Ringle, C. M., Wende, S., \& Becker, J.-M. (2015). SmartPLS 3. Retrieved from http://www.smartpls.com/

SoSci Survey Help. Retrieved from https://www.soscisurvey.de/help/doku.php/de:results:variables

Statista. (2017a). Anteil des Umsatzes von Amazon am gesamten Online-Handelsumsatz in Deutschland in den Jahren 2008 bis $2015 . \quad$ Retrieved from https://de.statista.com/statistik/daten/studie/669851/umfrage/marktanteil-von-amazon-im-onlinehandel-in-deutschland/

Statista. (2017b). Communication method preference for booking a holiday in the UK 2005-2013. Retrieved from https://www.statista.com/statistics/309650/communication-method-preference-for-booking-aholiday-uk/.

Statista. (2017c). Number of internet users and online shoppers in Germany from 2002 to 2013 (in millions). Retrieved from https://www.statista.com/statistics/445922/number-of-internet-users-onlineshoppers-germany/.

Steelman, Z. R., Hammer, B. I., \& Limayem, M. (2014). Data collection in the digital age: Innovative alternatives to student samples. MIS Quarterly, 38(2), 355-378.

van der Heijden, H., Verhagen, T., \& Creemers, M. (2003). Understanding online purchase intentions: contributions from technology and trust perspectives. European Journal of Information Systems, 12(1), 41-48.

Voorhees, C. M., Brady, M. K., Calantone, R., \& Ramirez, E. (2015). Discriminant validity testing in marketing: an analysis, causes for concern, and proposed remedies. Journal of the Academy of Marketing Science, 44, 119-134. 
Wells, J. D., Valacich, J. S., \& Hess, T. J. (2011). What signals are you sending? How website quality influences perceptions of product quality and purchase intentions. MIS Quarterly, 35(2), 373-396.

Werts, C. E., Linn, R. L., \& Jöreskog, K. G. (1974). Intraclass reliability estimates: Testing structural assumptions. Educational and Psychological Measurement, 34(1), 25-33.

Yoon, S.-J. (2002). The antecedents and consequences of trust in online-purchase decisions. Journal of Interactive Marketing, 16(2), 47-63.

Zucker, L. G. (1986). Production of trust: Institutional sources of economic structure. Research in Organizational Behavior, 1840-1920. 


\section{Appendix A: Sample Characteristics}

\begin{tabular}{|l|l|l|}
\hline \multicolumn{3}{|c|}{ Table A1. Sample Characteristics as reported by Fang et al. (2014) } \\
\hline 865 distributed questionnaires & 362 usable responses \\
\hline \multirow{3}{*}{ Of which were } & 695 business students & 170 faculty members \\
\cline { 2 - 3 } & $70 \%$ female & $30 \%$ male \\
\cline { 2 - 3 } & Mean age of 29 years. \\
\hline
\end{tabular}

\section{Appendix B: Questionnaire Items}

To improve the comparability, we used the same items as Fang et al. (2014) for the English version, the German items were translated according to the back translation method (Brislin, 1970).

Table B1. Original English Questionnaire Items and Back-Translated Items. Differences are highlighted.

\begin{tabular}{|c|c|c|}
\hline \multirow{2}{*}{\multicolumn{3}{|c|}{\begin{tabular}{|l|l} 
ID & Original Item \\
General Perceptions about Online Purchase
\end{tabular}}} \\
\hline & & \\
\hline \multicolumn{3}{|c|}{ Perceived Effectiveness of E-commerce Institutional Mechanisms (scale 1-7) } \\
\hline \multicolumn{2}{|c|}{$\begin{array}{l}\text { Below you will see a series of statements. If you agree with } \\
\text { a statement completely, please circle the number on the far } \\
\text { right. If you absolutely do not agree with a statement, please } \\
\text { circle the number on the far left. You can balance your } \\
\text { agreement or disagreement with the other numbers. }\end{array}$} & $\begin{array}{l}\text { Below you will see a set of statements. If you agree } \\
\text { with a statement completely, please select the option } \\
\text { on the far right. If you do not agree with a statement } \\
\text { at all, please choose the option on the far left. You } \\
\text { can balance your agreement or disagreement with } \\
\text { the other options. }\end{array}$ \\
\hline PEEIM1 & $\begin{array}{l}\text { When buying online, I am confident that there } \\
\text { are mechanisms in place to protect me } \\
\text { against any potential risks (e.g., leaking of } \\
\text { personal information, credit card fraud, goods } \\
\text { not received, etc.) of online shopping if } \\
\text { something goes wrong with my online } \\
\text { purchase. }\end{array}$ & $\begin{array}{l}\text { When buying online, I am confident that there are } \\
\text { mechanisms in place to protect me against any } \\
\text { potential risks (e.g., leaking of personal information, } \\
\text { credit card fraud, lost goods, etc.) of online shopping } \\
\text { if something goes wrong with my online purchase. }\end{array}$ \\
\hline PEEIM2 & $\begin{array}{l}\text { have confidence in third parties (e.g., } \\
\text { Trusted Shops, PayPal) to protect me against } \\
\text { any potential risks (e.g., leaking of personal } \\
\text { information, credit card fraud, goods not } \\
\text { received, etc.) of online shopping if something } \\
\text { goes wrong with my online purchase. }\end{array}$ & $\begin{array}{l}\text { I have confidence in third parties (e.g., SafeTrader, } \\
\text { TRUSTe) to protect me against any potential risks } \\
\text { (e.g., leaking of personal information, credit card } \\
\text { fraud, lost goods, etc.) of online shopping if } \\
\text { something goes wrong with my online purchase }\end{array}$ \\
\hline PEEIM3 & $\begin{array}{l}\text { I am sure that I cannot be taken advantage of } \\
\text { (e.g., leaking of personal information, credit } \\
\text { card fraud, goods not received, etc.) as a } \\
\text { result of conducting purchases online. }\end{array}$ & $\begin{array}{l}\text { I am sure that I cannot be taken advantage of (e.g., } \\
\text { leaking of personal information, credit card fraud, lost } \\
\frac{\text { goods, etc.) as a result of conducting purchases }}{\text { online. }}\end{array}$ \\
\hline PEEIM4 & $\begin{array}{l}\text { I believe that there are other parties (e.g., my } \\
\text { credit card company) who have an obligation } \\
\text { to protect me against any potential risks } \\
\text { (leaking of personal information, credit card } \\
\text { fraud, goods not received, etc.) of online } \\
\text { shopping if something goes wrong with my } \\
\text { online purchase. }\end{array}$ & $\begin{array}{l}\text { I believe that there are other parties (e.g., your credit } \\
\text { card company) who have an obligation to protect me } \\
\text { against any potential risks (leaking of personal } \\
\text { information, credit card fraud, lost goods, etc.) of } \\
\text { online shopping if something goes wrong with my } \\
\text { online purchase. }\end{array}$ \\
\hline \multicolumn{3}{|c|}{ Previous Satisfaction with Purchasing via the Internet (scale 1-7) } \\
\hline \multicolumn{2}{|c|}{$\begin{array}{l}\text { Please select the option that best describes how satisfied } \\
\text { you are with previous transactions via the Internet. }\end{array}$} & $\begin{array}{l}\text { Please circle the number that best describes how } \\
\text { satisfied you are with previous transactions on the } \\
\text { Internet. }\end{array}$ \\
\hline SI1 & Overall, extremely satisfied. & Overall, extremely satisfied. \\
\hline SI2 & Overall, extremely pleased. & Overall, extremely pleased. \\
\hline SI3 & My expectations were exceeded. & My expectations were exceeded. \\
\hline
\end{tabular}


Please circle the number that best describes how experienced you are with previous transactions via the Internet.

\begin{tabular}{l|l}
\hline EXP1 & I know a lot about conducting purchases via
\end{tabular} the Internet.

\begin{tabular}{l|l} 
EXP2 & I am experienced in conducting purchases via
\end{tabular} the Internet.

\begin{tabular}{l|l} 
EXP3 & I am an expert buyer of products/services via
\end{tabular} the Internet.

\begin{tabular}{l|l} 
EXP4 & I am informed about conducting purchases via
\end{tabular} the Internet.

\section{Perceptions about a Specific Vendor}

As you fill out this part, please think of a vendor you have purchased from recently via the internet. A vendor could either be an organisation or company that produces or provides the product or service (e.g., www.easyjet.com; www.blackstar.co.uk), or it could be an intermediary that sells various products or services (e.g., www.tesco.com). It doesn't matter which one you choose, as long as you keep it in mind as you fill out Part C. So that you are clear, please answer the following preliminary questions before you proceed:

\begin{tabular}{l|l} 
VEN & The vendor I am thinking of is:
\end{tabular} a company or brand that produces or provides the actual service an intermediary or wholesaler that sells a host of products and/or services on their Web site

\section{Repurchase Intention}

Please indicate the degree to which you agree with the following statements concerning your likelihood/probability of buying online again from the vendor you had in mind as you filled out this questionnaire.

\begin{tabular}{l|l} 
RPI1 & In the medium term \\
\hline RPI2 & In the long term \\
\hline RPI3 & $\begin{array}{l}\text { All things considered, and on a scale from 0- } \\
100 \%, \text { what is the probability that you will } \\
\text { purchase online from the same vendor again? }\end{array}$ \\
\hline
\end{tabular}

\section{Trust in Vendor (scale 1-7)}

Please indicate the degree to which you agree with the following statements concerning your trust to the vendor you had in mind as you filled out this questionnaire.

\begin{tabular}{|l|l|l|}
\hline TV1 & $\begin{array}{l}\text { I believe that this vendor is consistent in } \\
\text { quality and service. }\end{array}$ & $\begin{array}{l}\text { I believe that this vendor is consistent in quality and } \\
\text { service. }\end{array}$ \\
\hline TV2 & $\begin{array}{l}\text { I believe that this vendor is keen on fulfilling } \\
\text { my needs and wants. }\end{array}$ & $\begin{array}{l}\text { I believe that this vendor is eager to fulfil my needs } \\
\text { and wants. }\end{array}$ \\
\hline TV3 & $\begin{array}{l}\text { I believe that this vendor is honest. } \\
\text { I believe that this vendor is honest. } \\
\text { as one that keeps promises and } \\
\text { commitments. }\end{array}$ & $\begin{array}{l}\text { I believe that this vendor wants to be known as one } \\
\text { that keeps promises and commitments. }\end{array}$ \\
\hline TV5 & $\begin{array}{l}\text { I believe that this vendor has my best interests } \\
\text { in mind. }\end{array}$ & $\begin{array}{l}\text { I believe that this vendor has my best interests in } \\
\text { mind. }\end{array}$ \\
\hline TV6 & $\begin{array}{l}\text { I believe that this vendor is trustworthy. } \\
\text { I believe that this vendor is trustworthy. }\end{array}$ & \\
\hline TV7 & I believe that this vendor has high integrity. & I believe that this vendor has high integrity. \\
\hline TV8 & I believe that this vendor is dependable. & I believe that this vendor is dependable. \\
\hline TV9 & -- & Please select the option to the far right. \\
\hline Previous Satisfaction with Vendor (scale 1-7) & \\
\hline
\end{tabular}

Please select the option that best describes how experienced you are with past transactions on the Internet.

I know a lot about conducting purchases on the Internet.

I am experienced in conducting purchases on the Internet.

I am an expert buyer of products/services on the Internet.

I am informed about conducting purchases on the Internet.

As you fill out this part, please think of a vendor you have recently purchased from on the internet. A vendor could either be an organization or company that produces or provides the product or service (e.g., www.ryanair.com; www.apple.com), or it could be an intermediary that sells various products or services (e.g., www.amazon.com). It does not matter which one you choose, as long as you keep it in mind while you fill out the following parts.

So that you are clear on this, please answer the The vendor I am thinking of is:

a company or brand that produces or provides the actual service

an intermediary or wholesaler that sells a variety of products and/or services on their Web site

Please indicate the degree to which you agree with the following statements concerning your likelihood/probability of buying online again from the vendor you had in mind as you filled out this questionnaire.

In the medium term In the long term

All things considered, and on a scale from $0-100 \%$, what is the probability that you will purchase online from the same vendor again?

Please indicate the degree to which you agree with the following statements concerning your trust to the vendor you had in mind as you filled out this questionnaire.

I believe that this vendor is consistent in quality and I believe that this vendor is eager to fulfil my needs and wants.

I believe that this vendor is honest.

that this vendor wants to be known as one

I believe that this vendor has my best interests in mind.

I believe that this vendor is dependable.

Please select the option to the far right. following preliminary questions before you proceed. 
Please circle the number that best describes how satisfied you are with previous experiences with the vendor.

\begin{tabular}{|l|l}
\hline SV1 & Overall, extremely satisfied. \\
\hline SV2 & Overall, extremely pleased. \\
\hline SV3 & My expectations were exceeded. \\
\hline SV4 & I would recommend this vendor to a friend. \\
\hline
\end{tabular}

Vendor Image/Reputation (1-7 semantic differential)

Please circle the number that best describes your perception of the vendor you now have in mind on each of the attributes below.

\begin{tabular}{l|l}
\hline VR1 & Poor public image / Excellent public image \\
\hline VR2 & $\begin{array}{l}\text { Has a poor reputation / Has an excellent } \\
\text { reputation }\end{array}$
\end{tabular}

Perceived Website Quality (1-7 semantic differential)

Please circle the number that best describes your perception of the vendor's website on each of the attributes below.

\begin{tabular}{|l|l|}
\hline WQ1 & $\begin{array}{l}\text { Extremely difficult to use / Extremely easy to } \\
\text { use }\end{array}$ \\
\hline WQ2 & $\begin{array}{l}\text { Extremely poor organized / Extremely well } \\
\text { organized }\end{array}$ \\
\hline WQ3 & $\begin{array}{l}\text { Extremely difficult to navigate / Extremely } \\
\text { easy to navigate }\end{array}$ \\
\hline WQ4 & $\begin{array}{l}\text { Extremely difficult to find information that I } \\
\text { want / Extremely easy to find information that } \\
\text { I want }\end{array}$ \\
\hline WQ5 & $\begin{array}{l}\text { Extremely difficult to conduct online shopping } \\
\text { / Extremely easy to conduct online shopping }\end{array}$ \\
\hline WQ7 & $\begin{array}{l}\text { Extremely slow in transmitting words and } \\
\text { images / Extremely fast in transmitting words } \\
\text { and images }\end{array}$ \\
\hline Woor in terms of operational efficiency (e.g., \\
non-working links, etc.) / Excellent in terms of \\
operational efficiency (e.g., working links, \\
etc.)
\end{tabular}

Familiarity with Vendor (scale 1-7)

\begin{tabular}{l|l} 
FAM & Overall, how familiar are you with the vendor
\end{tabular} you now have in mind?

\section{Product Characteristics}

\begin{tabular}{l|l} 
PC1 & Approximately how much did the product or
\end{tabular} service you bought cost (in Euros)?

$\begin{array}{ll}\text { PC2 } & \text { What was the item you bought? }\end{array}$
Please select the option that best describes how satisfied you are with previous experiences with the vendor.

Overall, extremely satisfied.

Overall, extremely pleased.

My expectations were exceeded.

I would recommend this vendor to a friend.

Please select the option that best describes your perception of the vendor you now have in mind on each of the attributes below.

Bad public image / Excellent public image

Has a bad reputation / Has an excellent reputation

Please select the option that best describes your perception of the vendor's website on each of the attributes below.

Extremely difficult to use / Extremely easy to use

Extremely bad organized Extremely well organized

Extremely difficult to navigate / Extremely easy to navigate

Extremely difficult to find the information that I want / Extremely easy to find information that I want

Extremely difficult to shop online / Extremely easy to conduct online shopping

Extremely slow in transmitting words and images / Extremely fast in transmitting words and images

Poor in terms of operational efficiency (e.g., broken links, etc.) / Excellent in terms of operational efficiency (e.g., working links, etc.)

Extremely useless search/help functions / Extremely useful search/help functions

Extremely uninteresting / Extremely interesting

Extremely unexciting / Extremely exciting

Extremely boring / Extremely entertaining

Extremely unclear layout / Extremely clear layout

Low attention-grabbing ability High attentiongrabbing ability

Please select the option to the far left.

Overall, how familiar are you with the vendor you currently have in mind?

Approximately how much did the product or service you bought cost (in Euros)?

What was the item you bought? 
Table B2. Translated German Questionnaire Items.

\begin{tabular}{l|l}
\hline ID & Item \\
\hline General Perceptions
\end{tabular}

General Perceptions about Online Purchase

Perceived Effectiveness of E-commerce Institutional Mechanisms (scale 1-7)

Nachfolgend lesen Sie eine Reihe von Aussagen. Wenn Sie einer Aussage voll und ganz zustimmen, wählen Sie in der entsprechenden Zeile bitte die Auswahloption ganz rechts. Wenn Sie der Aussage gar nicht zustimmen, wählen Sie bitte die Auswahloption ganz links. Mit den Auswahloptionen dazwischen können Sie Ihre Beurteilung abstufen.

PEEIM1 $\quad$ Beim Online-Kauf bin ich überzeugt, dass Mechanismen vorhanden sind, die mich gegen jegliche potenziellen Risiken (z. B. Verbreitung persönlicher Daten, Kreditkartenbetrug, nicht erhaltene Waren usw.) des Online-Einkaufs schützen, wenn mit meinem Online-Kauf etwas schiefgeht.

PEEIM2 $\quad$ Ich vertraue darauf, dass Dritte (z. B. Trusted Shops, PayPal) mich gegen jegliche potenziellen Risiken (z. B. Verbreitung persönlicher Daten, Kreditkartenbetrug, nicht erhaltene Waren usw.) des Online-Einkaufs schützen, wenn mit meinem Online-Kauf etwas schiefgeht.

PEEIM3 $\quad$ Ich bin mir sicher, dass ich infolge der Durchführung eines Online-Kaufs nicht ausgenutzt werden kann (z. B. durch Verbreitung persönlicher Daten, Kreditkartenbetrug, nicht erhaltene Waren usw.).

PEEIM4 $\quad$ Ich glaube, dass es andere Unternehmen und Organisationen gibt (z. B. mein Kreditkartenunternehmen), die verpflichtet sind, mich gegen jegliche potenziellen Risiken (Verbreitung persönlicher Daten, Kreditkartenbetrug, nicht erhaltene Waren, etc.) des Online-Einkaufs zu schützen, wenn mit meinem Online-Kauf etwas schiefgeht.

Previous Satisfaction with Purchasing via the Internet (scale 1-7)

Bitte wählen Sie die Option an, die am besten beschreibt, wie zufrieden Sie mit früheren, über das Internet getätigten Transaktionen sind.

\begin{tabular}{l|l} 
SI1 & Insgesamt sehr zufrieden.
\end{tabular}

\begin{tabular}{l|l} 
SI2 & Insgesamt sehr überzeugt.
\end{tabular}

\begin{tabular}{l|l} 
SI3 & Meine Erwartungen wurden übertroffen.
\end{tabular}

Expertise in Using the Internet to Conduct Transaction (scale 1-7)

Bitte wählen Sie die Option an, die am besten beschreibt, welche Erfahrungen Sie mit früheren, über das Internet getätigten Transaktionen gemacht haben.

EXP1 $\quad$ Ich kenne mich mit der Durchführung von Einkäufen über das Internet gut aus.

EXP2 $\quad$ Ich habe Erfahrung mit der Durchführung von Käufen über das Internet.

EXP3 $\quad$ Ich bin ein fachkundiger Käufer von Produkten/Diensten, die über das Internet angeboten werden.

EXP4 $\quad$ Ich weiß über die Durchführung von Einkäufen über das Internet Bescheid.

Perceptions about a Specific Vendor

Denken Sie beim Ausfüllen dieses Abschnitts bitte an einen Verkäufer, von dem Sie kürzlich über das Internet Ware erworben haben. Ein Verkäufer kann entweder eine Organisation oder ein Unternehmen sein, die/das das jeweilige Produkt / den jeweiligen Dienst anbietet oder erstellt (z. B. www.ryanair.com; www.apple.com), oder aber ein Zwischenhändler, der verschiedene Produkte oder Dienste zum Kauf anbietet (z. B. www.amazon.de). Es spielt keine Rolle, für welchen Verkäufer Sie sich entscheiden, solange Sie sich beim weiteren Ausfüllen auf diesen beziehen.

Bitte beantworten Sie - nur, damit Sie sich darüber im Klaren sind - die folgenden einleitenden Fragen, ehe Sie fortfahren.

\begin{tabular}{l|l} 
VEN & Der Verkäufer, für den ich mich entschieden habe ist:
\end{tabular}

ein Unternehmen oder eine Marke, welche(s) den jeweiligen Dienst erstellt oder anbietet

ein Zwischenhändler oder Großhändler, der über seine Internetseite sehr viele Produkte und/oder Dienste verkauft

\section{Repurchase Intention}

Wie groß ist die Wahrscheinlichkeit, dass Sie bei dem Verkäufer, der Ihnen beim Ausfüllen dieses Fragebogens vorschwebt, erneut online kaufen?

\begin{tabular}{|l|l|}
\hline RPI1 & Mittelfristig \\
\hline RPI2 & Auf lange Sicht \\
\hline RPI3 & $\begin{array}{l}\text { Alles in allem, auf einer Skala von 0 - 100 \%, wie hoch ist die Wahrscheinlichkeit, dass Sie über das } \\
\text { Internet erneut vom gleichen Verkäufer kaufen werden? }\end{array}$ \\
\hline Trust in Vendor (scale 1-7) \\
\hline $\begin{array}{l}\text { Im Folgenden sehen Sie Aussagen bezüglich Ihres Vertrauens gegenüber des Verkäufer, der Ihnen beim Ausfüllen } \\
\text { dieses Fragebogens vorschwebt. Bitte geben Sie an, wie sehr Sie den jeweiligen Aussagen zustimmen. }\end{array}$ \\
\hline TV1 & $\begin{array}{l}\text { Ich glaube, dass bei diesem Verkäufer Qualität und Service gleichbleibend sind. } \\
\text { TV2 } \\
\text { gerecht zu werden. }\end{array}$ \\
\hline TV3 & $\begin{array}{l}\text { Ich glaube, dass dieser Verkäufer ehrlich ist. } \\
\text { einzuhalten. }\end{array}$ \\
\hline
\end{tabular}




\begin{tabular}{|c|c|}
\hline TV5 & Ich glaube, dass dieser Verkäufer mein Interesse im Sinn hat. \\
\hline TV6 & Ich glaube, dass dieser Verkäufer vertrauenswürdig ist. \\
\hline TV7 & Ich glaube, dass dieser Verkäufer hohe Integrität besitzt. \\
\hline TV8 & Ich glaube, dass dieser Verkäufer zuverlässig ist. \\
\hline TV9 & Wählen Sie bitte die Option ganz rechts \\
\hline \multicolumn{2}{|c|}{ Previous Satisfaction with Vendor (scale 1-7) } \\
\hline \multicolumn{2}{|c|}{$\begin{array}{l}\text { Bitte wählen Sie die Option an, die am besten beschreibt, wie zufrieden Sie mit früheren Erfahrungen sind, die Sie } \\
\text { mit dem Verkäufer gemacht haben. }\end{array}$} \\
\hline SV1 & Insgesamt sehr zufrieden. \\
\hline SV2 & Insgesamt sehr überzeugt. \\
\hline SV3 & Meine Erwartungen wurden übertroffen. \\
\hline SV4 & Ich würde einem Freund / einer Freundin diesen Verkäufer weiterempfehlen. \\
\hline \multicolumn{2}{|c|}{ Vendor Image/Reputation (1-7 semantic differential) } \\
\hline \multicolumn{2}{|c|}{$\begin{array}{l}\text { Bitte wählen Sie bei jeder der folgenden Merkmale die Option an, die Ihre Einschätzung des von Ihnen gewählten } \\
\text { Verkäufers am besten beschreibt. }\end{array}$} \\
\hline VR1 & Sehr schlechtes öffentliches Ansehen / Hervorragendes öffentliches Ansehen \\
\hline VR2 & Verfügt über einen sehr schlechten Ruf / Verfügt über einen ausgezeichneten Ruf \\
\hline \multicolumn{2}{|c|}{ Perceived Website Quality (1-7 semantic differential) } \\
\hline \multicolumn{2}{|c|}{$\begin{array}{l}\text { Bitte wählen Sie bei jeder der folgenden Merkmale die Option an, die Ihre Einschätzung der Internetseite des } \\
\text { Verkäufers am besten beschreibt. }\end{array}$} \\
\hline WQ1 & Besonders schwer zu nutzen / Besonders einfach zu nutzen \\
\hline WQ2 & Besonders schlecht organisiert / Besonders gut organisiert \\
\hline WQ3 & Besonders schwer zu navigieren / Besonders einfach zu navigieren \\
\hline WQ4 & $\begin{array}{l}\text { Es ist besonders schwer, die von mir benötigten Informationen zu finden / Es ist besonders einfach, } \\
\text { die von mir benötigten Informationen zu finden }\end{array}$ \\
\hline WQ5 & $\begin{array}{l}\text { Es ist besonders schwer, Online-Einkäufe durchzuführen / Es ist besonders einfach, Online-Einkäufe } \\
\text { durchzuführen }\end{array}$ \\
\hline WQ6 & $\begin{array}{l}\text { Die Übertragung von Text und Bildern ist besonders langsam / Die Übertragung von Text und Bildern } \\
\text { ist besonders schnell }\end{array}$ \\
\hline WQ7 & $\begin{array}{l}\text { Extrem schlecht in Bezug auf operative Effizienz (z. B. durch nicht funktionierende Links usw.) / } \\
\text { Hervorragend in Bezug auf operative Effizienz (z. B. durch funktionierende Links usw.) }\end{array}$ \\
\hline WQ8 & Besonders unnützliche Such-/Hilfefunktionen / Besonders nützliche Such-/Hilfefunktionen \\
\hline WQ9 & Besonders uninteressant / Besonders interessant \\
\hline WQ10 & Besonders wenig aufregend / Besonders aufregend \\
\hline WQ11 & Besonders wenig unterhaltsam / Besonders unterhaltsam \\
\hline WQ12 & Besonders unübersichtliche Aufmachung / Besonders übersichtliche Aufmachung \\
\hline WQ13 & Geringe Fähigkeit, Aufmerksamkeit zu erregen / Große Fähigkeit, Aufmerksamkeit zu erregen \\
\hline WQ14 & Wählen Sie bitte die Option ganz links \\
\hline \multicolumn{2}{|c|}{ Familiarity with Vendor (scale 1-7) } \\
\hline FAM & Alles in allem, wie vertraut ist Ihnen der Verkäufer, der Ihnen vorschwebt? \\
\hline \multicolumn{2}{|c|}{ Product Characteristics } \\
\hline PC1 & $\begin{array}{l}\text { Wie viel hat das Produkt oder der Dienst, das/den Sie in Anspruch genommen haben, ungefähr } \\
\text { gekostet (in Euro)? }\end{array}$ \\
\hline PC2 & Worum handelte es sich bei Ihrem Kauf? \\
\hline
\end{tabular}

\section{Appendix C: Multi-Group Analysis}

Table $\mathrm{C} 1$ shows the results of the multi-group analysis (MGA) for the two groups goods and services. The MGA was calculated with SmartPLS (Ringle et al., 2015). Electronics, clothes, sports equipment, household items, and kitchen items are categorized in goods. Services contain flight tickets, hotel bookings, concerts, books, and movies. Books and movies are in the category of services because purchasers buy and consume them and generally they cannot be refunded once books have been read or movies watched. Figure C1 shows the differences between the two groups, while Figure C2 and Figure C3 show the estimated path models for goods and services, respectively. 


\begin{tabular}{|c|c|c|c|c|c|c|}
\hline \multicolumn{7}{|c|}{ Table C1. Model Estimates (Goods vs. Services) } \\
\hline & \multicolumn{3}{|c|}{ Goods } & \multicolumn{3}{|c|}{ Services } \\
\hline Path & Weight & t value & p value & Weight & t value & p value \\
\hline \multicolumn{7}{|c|}{ Main Model } \\
\hline $\mathrm{SV} \rightarrow \mathrm{TV}$ & .600 & 9.913 & .000 & .595 & 8.397 & .000 \\
\hline PEEIM $\rightarrow$ TV & .180 & 4.972 & .000 & .231 & 5.005 & .000 \\
\hline PEEIM * SV $\rightarrow$ TV & -.025 & .620 & .535 & -.076 & 1.549 & .121 \\
\hline $\mathrm{TV} \rightarrow \mathrm{RPI}$ & -.047 & .646 & .518 & -.074 & .856 & .392 \\
\hline PEEIM * TV $\rightarrow$ RPI & -.081 & .610 & .542 & -.216 & 2.539 & .011 \\
\hline $\mathrm{SV} \rightarrow \mathrm{RPI}$ & .422 & 4.476 & .000 & .543 & 5.226 & .000 \\
\hline PEEIM $\rightarrow$ RPI & -.006 & .130 & .897 & -.105 & 1.555 & .120 \\
\hline \multicolumn{7}{|c|}{ Control Variables } \\
\hline $\mathrm{WQ} \rightarrow \mathrm{TV}$ & .017 & .408 & .683 & .016 & .345 & .730 \\
\hline $\mathrm{WQ} \rightarrow \mathrm{RPI}$ & .196 & 3.586 & .000 & .147 & 2.621 & .009 \\
\hline $\mathrm{VR} \rightarrow \mathrm{TV}$ & .215 & 5.352 & .000 & .127 & 2.459 & .014 \\
\hline $\mathrm{VR} \rightarrow \mathrm{RPI}$ & -.102 & 2.213 & .027 & -.081 & 1.476 & .140 \\
\hline $\mathrm{FV} \rightarrow \mathrm{TV}$ & .041 & .873 & .383 & .066 & 1.551 & .121 \\
\hline $\mathrm{FV} \rightarrow \mathrm{RPI}$ & .297 & 4.337 & .000 & .142 & 1.923 & .055 \\
\hline $\mathrm{SI} \rightarrow \mathrm{TV}$ & -.036 & .800 & .424 & .013 & .203 & .839 \\
\hline $\mathrm{SI} \rightarrow \mathrm{RPI}$ & .082 & 1.421 & .155 & .092 & 1.239 & .215 \\
\hline Gender $\rightarrow \mathrm{RPI}$ & -.028 & .669 & .503 & -.032 & .721 & .471 \\
\hline Income $\rightarrow$ RPI & .069 & 1.679 & .093 & .084 & 1.536 & .125 \\
\hline Education $\rightarrow$ RPI & -.012 & .302 & .763 & -.050 & 1.204 & .229 \\
\hline Expertise $\rightarrow$ RPI & -.013 & .266 & .790 & .180 & 2.879 & .004 \\
\hline Product Characteristic & -.053 & .654 & .513 & .016 & .356 & .722 \\
\hline
\end{tabular}

.121

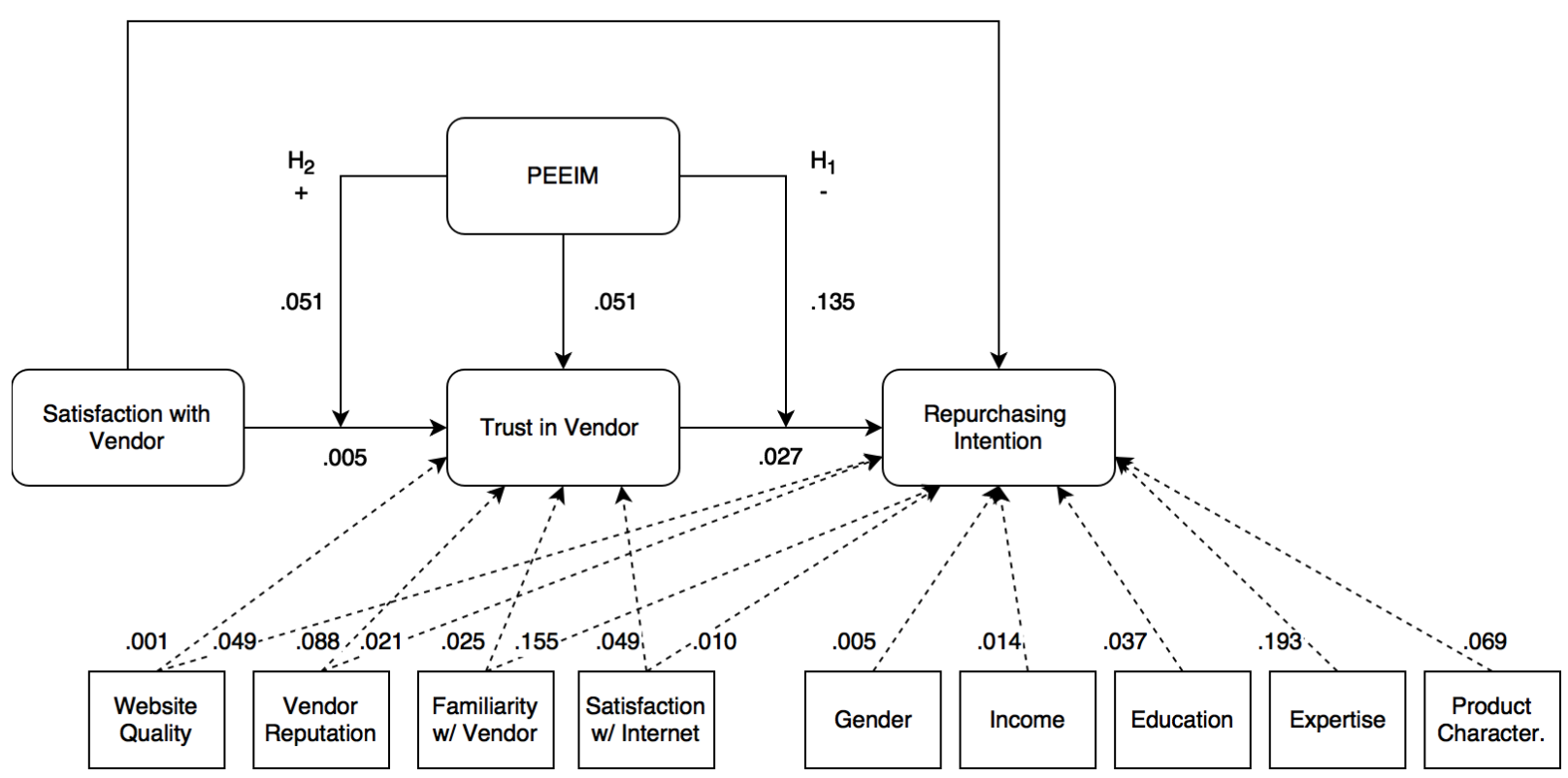

Figure C1. Research Model with absolute path weight differences between goods and services.

${ }^{\star}: p<.05 ;{ }^{* *}: p<.01 ;{ }^{* \star \star}: p<.001$; dotted lines represent non-significant differences in effects of controlvariables 


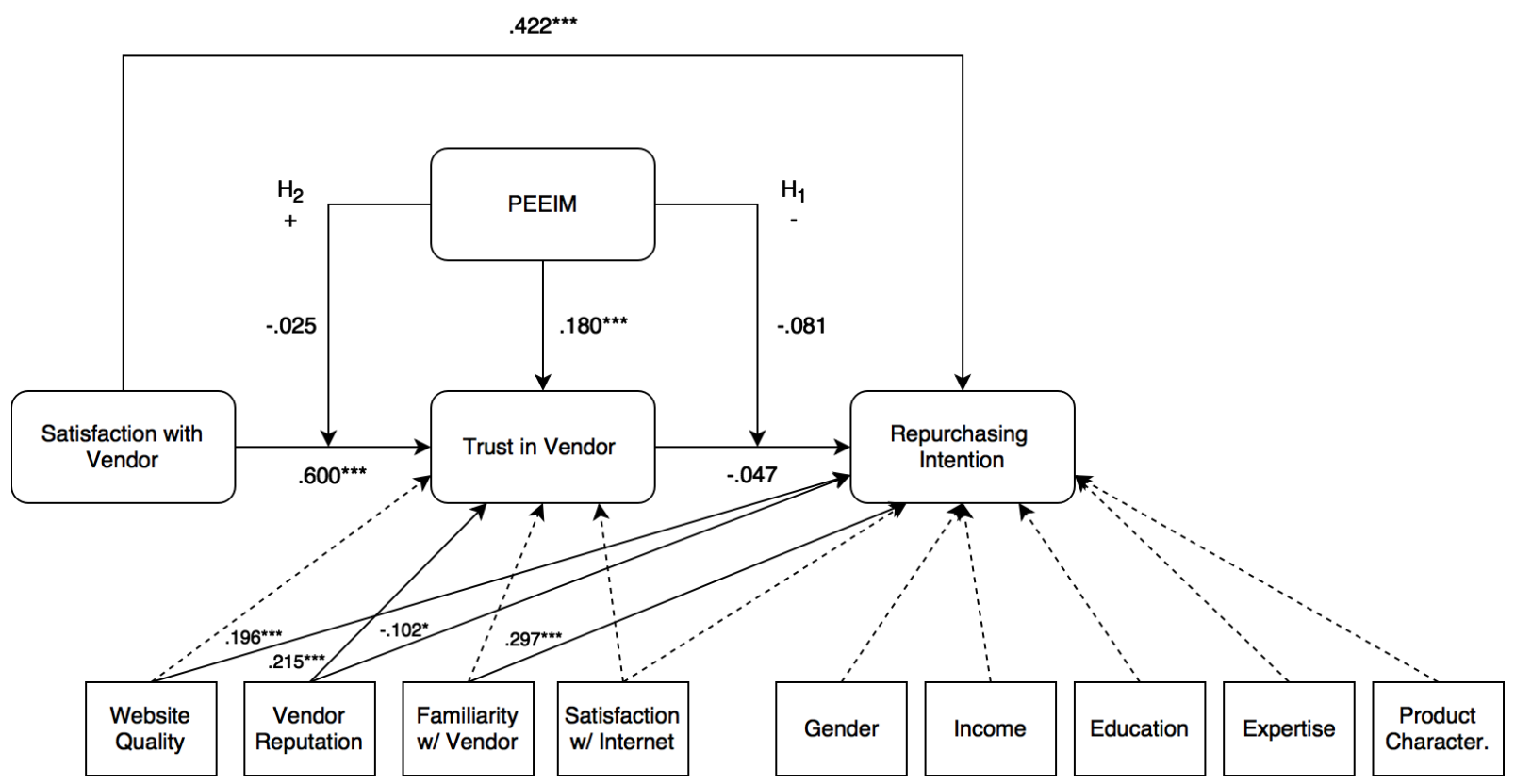

Figure C2. Estimated Research Model (Goods)

${ }^{*}: p<.05 ;{ }^{* *}: p<.01 ;{ }^{* * *}: p<.001 ;$ dotted lines represent non-significant control-variables

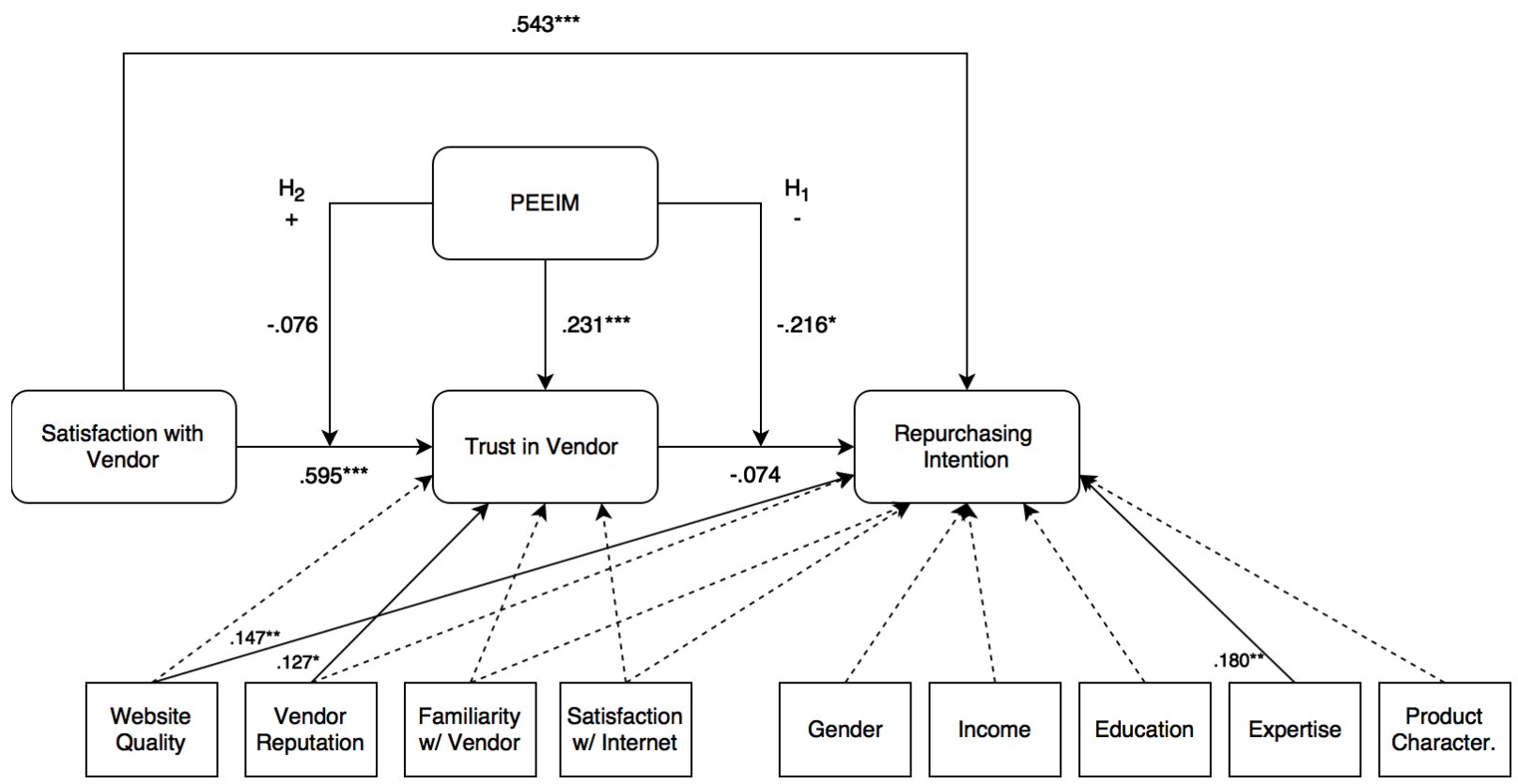

Figure C3. Estimated Research Model (Services)

${ }^{*}: \mathrm{p}<.05 ;{ }^{* *}: \mathrm{p}<.01 ;{ }^{* * *}: \mathrm{p}<.001 ;$ dotted lines represent non-significant control-variables 


\section{About the Authors}

Phil Diegmann. He is a PhD-Student and Research Assistant. He holds bachelor's and master's degrees in information systems from the University of Cologne, Germany. Currently he is pursuing his $\mathrm{PhD}$ at the Professorship of Information Systems and Integrated Information Systems at the University of Cologne. His research interests cover the management of IT projects and the composition of agile IS development teams, especially in regard to diversity and time pressure. His research has been published in the Project Management Journal and in proceedings of international conferences and workshops, such as the International Conference on Information Systems, Americas Conference on Information Systems, Wirtschaftsinformatik, and the International Research Workshop on IT Project Management.

Can Dogan. He is a master's degree student in information systems at the University of Cologne, Germany. His research focuses on optimizing unstructured data with artificial neural networks. During his studies, he worked for IBM Germany and the professorship for informatics of Prof. Dr. Jünger. As part of his master's degree, Can Dogan attended the Triple Crown accredited Sun Yat-Sen Business School in Guangzhou, China.

Martin Brandt. He is a master's degree student in information systems at the University of Cologne, Germany. Currently he is researching artificial intelligence in connection with financial services. His main field of interest are innovative solutions for healthcare.

Dirk Basten. He is an Assistant Professor at the Department of Information Systems and Systems Development at the University of Cologne, Germany. His research focuses on IS project success, software development effort estimation, knowledge management in project and program contexts, and Gamification. His works have appeared in journals such as Information \& Management, Project Management Journal, Journal of Computer Information Systems, Communications of the Association for Information Systems, IEEE Computer, IEEE Software, and the proceedings of conferences such as HICSS, ECIS, AMCIS, and ICIS.

Christoph Rosenkranz. He is a Full Professor of Information Systems at University of Cologne, Germany. He holds Diploma and doctoral degrees from the University of Münster and Goethe University, respectively. His research focuses on integrated information systems as socio-technical systems, business process management, information systems development and IT project management, and IT outsourcing. He has published articles in such outlets as ACM Transactions on Management Information Systems, Business \& Information Systems Engineering, European Journal of Information Systems, Information Systems Journal, Journal of Database Management, Journal of Information Technology, and Journal of the Association for Information Systems.

Copyright @ 2018 by the Association for Information Systems. Permission to make digital or hard copies of all or part of this work for personal or classroom use is granted without fee provided that copies are not made or distributed for profit or commercial advantage and that copies bear this notice and full citation on the first page. Copyright for components of this work owned by others than the Association for Information Systems must be honored. Abstracting with credit is permitted. To copy otherwise, to republish, to post on servers, or to redistribute to lists requires prior specific permission and/or fee. Request permission to publish from: AIS Administrative Office, P.O. Box 2712 Atlanta, GA, 30301-2712 Attn: Reprints or via e-mail from ais@aisnet.org. 